This is a preprint of a chapter accepted for publication by Facet Publishing.

This extract has been taken from the author's original manuscript and has not been edited.

The definitive version of this piece may be found in 'Partners for Preservation:

Advancing digital preservation through cross-community collaboration' Facet, London, 9781783303472

which can be purchased from http://www.facetpublishing.co.uk/title.php?id=303472\#about-tab

\title{
Inheritance of Digital Media
}

Dr Edina Harbinja, University of Hertfordshire

\section{Introduction}

We live in a world where our entire identities are created, developed and stored online, in different accounts owned by various service providers, such as Google, Facebook, Instagram, Twitter, Apple, Microsoft etc. Once users who engage with all or some of this die, ${ }^{1}$ many interesting and concerning questions for lawyers, but also the wider public, arise. Stakeholders who would have a stake after this unfortunate event may include the deceased's family and heirs, friends, service providers, researchers, historians, archivists and sometimes, the public. There have been many cases reported in the media depicting some of these interests and their conflicts, albeit case law is still very scarce in most countries. ${ }^{2}$ These cases related to some key questions that have largely remained unanswered, such as: Should bereaved family members be allowed to access the dead user's digital accounts? Is the service provider obliged to enable the family this access? Should friends have access to the shared content on Facebook? Do users have a right to decide what happens to these accounts when they die? What about the right of access by the wider public, journalists, archivists and historians in particular? All these questions reveal the complexity of digital assets, remains and posthumous identities. Yet still, in the UK a credible research has found that $85 \%$ of participants ${ }^{3}$ are not considering the implications of digital death. In this chapter, I aim to shed some light on these questions and offer some mainly legal solutions, but looking at their wider implications as well.

Legal scholarship in the area is now quite abundant, and may authors have embarked upon identifying key issues in laws related to digital death, as well as offering some solutions and ideas. ${ }^{4}$ This author is one of them and has been writing about the topic for more than 6 years now. ${ }^{5}$ In spite of this, many

\footnotetext{
${ }^{1}$ See for instance Evan Carroll, "1.7 Million U.S. Facebook Users Will Pass Away in 2018”, The Digital Beyond, January, 23, 2018, <http://www.thedigitalbeyond.com/2018/01/1-7-million-u-s-facebook-users-will-passaway-in-2018/>.

2 E.g. BBC NEWS, “Who Owns Your E-mails?”, January 11, 2005, http:// news.bbc.co.uk/1/hi/magazine/4164669.stm; Paul Sancya, "Yahoo Will Give Family Slain Marine's E-Mail Account", USA TODAY, April 21, 2005, http://usatoday30.usatoday.com/tech/news/2005-04-21-marineemail x.htm?POE=TECISVA; Lauren Gambino, "In Death, Facebook Photos Could Fade Away Forever", Associated Press, March 1, $2013<$ www.yahoo.com/news/death-facebook-photos-could-fade-away-forever085129756--finance.html>; “Karen Williams' Facebook Saga Raises Question of Whether Users' Profiles Are Part of "Digital Estates"”, The Huffington Post, March 15, 2012, https://www.reddit.com/r/privacy/comments/r6rz9/karen williams facebook saga raises question of/ 3 Digital Legacy Association, “Digital Death Survey 2017”, 2017, <https://digitallegacyassociation.org/wp-
} content/uploads/2018/02/Digital-Legacy-Association-Digital-Death-Survey-Data.htm>

\footnotetext{
${ }^{4}$ E.g. Naomi Cahn “Postmortem Life On-Line”, Prob. \& Prop, 25, (2011):, 36-37; Maria Perrone, “What Happens When We Die: Estate Planning of Digital Assets", CommLaw Conspectus 185, 21(2012/2013) Samantha D. Haworth "Laying Your Online Self to Rest: Evaluating the Uniform Fiduciary Access to Digital Assets Act" $68 \mathrm{U}$. Miami L. Rev. 535, 538; J P Hopkins, 'Aferlife in the Cloud: Managing a Digital Estate' (2013) 5 Hastings Sci. \& Tech L.J., (2014): 211; Delia Băbeanu et al., "Strategic Outlines: Between Value and Digital Assets Management" 11 Annales Universitatis Apulensis Series Oeconomica 318, (2009): 319; 115; Alberto B. LOPEZ, "Posthumous Privacy, Decedent Intent, and Post-mortem Access to Digital Assets", 24 George Mason Law Review, (2016): 183; Damien McCallig "Facebook after death: an evolving policy in a social network" Int'l JL \& Info Tech (2013): 1.

${ }^{5}$ Lilian Edwards and Edina Harbinja, "What Happens to My Facebook Profile When I Die? Legal Issues Around Transmission of Digital Assets on Death" in Digital Legacy And Interaction: Post-Mortem Issues, eds. C Maciel and V Pereira, (Springer, 2013); Lilian Edwards and Edina Harbinja "Protecting Post-Mortem Privacy:
} 


\author{
This is a preprint of a chapter accepted for publication by Facet Publishing. \\ This extract has been taken from the author's original manuscript and has not been edited. \\ The definitive version of this piece may be found in 'Partners for Preservation: \\ Advancing digital preservation through cross-community collaboration' Facet, London, 9781783303472 \\ which can be purchased from http://www.facetpublishing.co.uk/title.php?id=303472\#about-tab
}

western jurisdictions still struggle to find the right (or any) response to the conundrum of questions around regulation of digital assets on death. No western country so far has found an optimal solution, which would consolidate and resolve issues arising in many different areas of law and regulation. There have been some welcome, albeit sporadic, attempt to legislate and we will look at some of these in the chapter. I will also aim to provide some considerations as to where regulation and technology could go next in order to improve this area and bring about more clarity for users, platforms, practitioners, archivists and the public.

The chapter starts with looking at some conceptual issues around what digital assets are and whether it is useful to offer a comprehensive definition. Further, I will examine key legal issues for any jurisdiction, focusing on the examples of the UK and America. These are property, ownership and copyright that digital assets might include. In the following section, we will look at service providers' contract and terms of service, that govern the assets on a more global level. Some technological solutions will be examined here too. Following the exploration of these, I will look at the notion of post-mortem privacy and examine whether there is a case for establishing this concept more strongly in law, regulation and technology. The chapter will conclude by evaluating estate planning options and offering some solutions as a way forward.

\title{
2. The concept of digital assets - what is included in digital inheritance?
}

The notion of digital assets is a relatively new phenomenon in the UK and globally, lacking a proper legal definition, with diverse meanings attributed to it. ${ }^{6}$ For instance, from a layman's perspective, it could be anything valuable online, any asset (account, file, document, digital footprint; music library, social media account, pictures, videos, different online collections, bitcoin wallets) that has a personal, economic or social attachment to an individual. The legal meaning, however, needs a little more precision. Constructing its legal definition and nature would enable adequate legal treatment and regulation. On the other hand, an overly narrow definition would risk leaving out assets that do not fit in, or technologies that emerge. So far, there have been a fair few attempts to define and classify them. ${ }^{7}$ Most of the definitions are, however, inductive and try to theorise starting from the

Reconsidering the Privacy Interests of the Deceased in a Digital World", Cardozo Arts \& Entertainment, 32(1), (2013): 101; Edina Harbinja, "Virtual Worlds - a Legal Post-Mortem Account", SCRIPT-ed 10(3). (2014): 273, https://script-ed.org/article/virtual-worlds-a-legal-post-mortem-account/; Edina Harbinja, "Virtual worlds players - consumers or citizens?", Internet Policy Review 3(4) (2014),

https://policyreview.info/articles/analysis/virtual-worlds-players-consumers-or-citizens; Edina Harbinja, "Legal Nature of Emails: A Comparative Perspective", 14 Duke Law and Technology Review (2016): 227, http://scholarship.law.duke.edu/dltr/vol14/iss1/10; Edina Harbinja, "Post-mortem privacy 2.0: Theory, law and technology", 31 International Review of Law, Computers \& Technology (2017), http://www.tandfonline.com/doi/citedby/10.1080/13600869.2017.1275116?scroll=top\&needAccess=true; Edina Harbinja, "What happens to our digital assets when we die?", Lexis PSL, November 2016; Edina Harbinja, "Social media and death" in The Legal Challenges of Social Media, eds. Lorna Gillies and David Mangan (Edward Elgar Publishing, 2017); Edina Harbinja, "Digital Inheritance in the United Kingdom”, The Journal of European Consumer and Market Law (EuCML), December 2017.

${ }^{6}$ See e.g. Heather Conway \& Sheena Grattan, "The 'New' New Property: Dealing with Digital Assets on Death" In Modern Studies in Property Law, Eds, Heather Conway \& Robin Hickey (2017, Hart Publishing, Oxford).

${ }^{7}$ Cahn, "Postmortem Life On-Line", 36-37; Perrone. "What Happens When We Die: Estate Planning of Digital Assets' (2012/2013) 21 CommLaw Conspectus 185; S Haworth 'Laying Your Online Self to Rest: Evaluating the Uniform Fiduciary Access to Digital Assets Act”, 538; Hopkins, “Aferlife in the Cloud: Managing a Digital Estate", 211; Băbeanu et al., "Strategic Outlines: Between Value and Digital Assets Management", 319; Edwards and Harbinja, "What Happens to My Facebook Profile When I Die? Legal Issues Around Transmission of Digital Assets on Death", 115. 


$$
\begin{aligned}
& \text { This is a preprint of a chapter accepted for publication by Facet Publishing. } \\
& \text { This extract has been taken from the author's original manuscript and has not been edited. } \\
& \text { The definitive version of this piece may be found in 'Partners for Preservation: } \\
& \text { Advancing digital preservation through cross-community collaboration' Facet, London, } 9781783303472 \\
& \text { which can be purchased from http://www.facetpublishing.co.uk/title.php?id=303472\#about-tab }
\end{aligned}
$$

existing assets online, trying to make appropriate generalisations and classifications. ${ }^{8}$ Harbinja and Edwards also attempted to define it in their early work in the area. ${ }^{9}$ In my more recent work, I propose that digital assets are defined as any intangible asset of personal or economic value created, purchased or stored online. ${ }^{10}$ These assets could fall within existing institutions of property, rights under the contract, intellectual property, personality right or personal data. Another element should be to exclude from the definition the infrastructure of hosts, social media sites and websites which they create and maintain e.g. cloud storage, as opposed to the accounts and assets created and occupied by users. This is for the reason that the infrastructure is owned or protected by their intellectual property rights and only serves as an enabler for the creation and storage of assets that are physically and logically placed above that layer of the internet. ${ }^{11}$

Digital assets have become significantly valuable to online users in the UK and worldwide. As early as October 2011, the Centre for Creative and Social Technology (CAST) at Goldsmiths, University of London, released a study of Internet use in the UK entitled 'Generation Cloud'. The study determined that British users have at least GBP 2.3 billion worth of digital assets stored in the cloud. The study shows that 24 percent of UK adults estimate that they have digital assets worth more than $£ 200$ per person in the cloud, which amounts to at least $£ 2.3 \mathrm{bn}$ in total. ${ }^{12}$ At the same time, McAfee conducted a global study and found that respondents had 2,777 digital files stored on at least one device, at a total value of $\$ 37,438$, with US users valuing their assets at nearly $\$ 55,000 .{ }^{13} \mathrm{PwC}$ conducted a similar survey in 2013 and found that the users value their digital assets at $f 25$ billion. ${ }^{14}$ Given the exponential growth in digital usage between 2013 and 2018, this figure would be even higher now. However, there is a lack of recent empirical data to evidence this now.

Despite the growing value and importance, the area and the applicable laws are far from clear in the UK and elsewhere in the world. Users, practitioners and service providers struggle to navigate through the complex laws around property law, wills and succession, trusts, intellectual property, data protection, contracts, jurisdiction. All these areas are relevant when discussing digital assets and their transmission on death. ${ }^{15}$ In the next section, I will try to outline some of the key issues that users, practitioners, intermediaries, archivists and others might encounter when dealing with digital assets.

\title{
3. Key legal issues - property, copyright and access
}

\author{
${ }^{8}$ Edina Harbinja, "Legal Aspects of Transmission of Digital Assets on Death" (PhD diss, University of \\ Strathclyde, 2017), 18-25. \\ ${ }^{9}$ Edwards \& Harbinja, “What Happens to My Facebook Profile When I Die?': Legal Issues Around Transmission \\ of Digital Assets on Death" \\ ${ }^{10}$ See Harbinja, "Legal Aspects of Transmission of Digital Assets on Death", 24-25. \\ 11 Ibid 121, 220-225, $245-268$. \\ ${ }^{12}$ Rackspace Hosting "Generation Cloud: A social study into the impact of cloud-based services on everyday UK \\ life", November 16, 2011, http://www.rackspace.co.uk/sites/default/files/whitepapers/generation cloud.pdf. \\ ${ }^{13}$ McAfee, "How Do Your Digital Assets Compare?” May 14, 2013 \\ https://securingtomorrow.mcafee.com/consumer/family-safety/digital-assets/ \\ ${ }^{14}$ PwC, 'Digital lives: we value our digital assets at $\mathrm{f25}$ billion', PWC, 2013, \\ https://www.pwc.co.uk/issues/cyber-security-data-privacy/insights/digital-lives-we-value-our-digital-assets- \\ at-25-billion.html \\ ${ }^{15}$ Harbinja, "Legal Aspects of Transmission of Digital Assets on Death", 13-18.
}




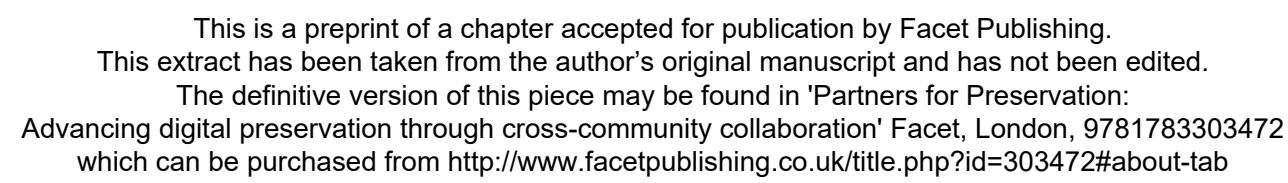

One of the crucial legal issues in this area relates to the question whether the content and/or user's account can be considered the user's property or not. This is the first legal concept anyone refers to when they think about what they think they 'own'. Thus users might refer to owning their Facebook account, emails, iTunes or Spotify library, YouTube channel, gaming and MMOPG (massively multiplayer online playing games) account etc. Ownership in all of these cases, however, far from what users might expect it to be. It is not property and ownership in the sense of their physical possession such as their house, their car or even their poem or novel. This is much more complex during the user's life, and the complexity of law increases once a user passes away. I have examined these on examples of emails, ${ }^{16}$ social network accounts ${ }^{17}$ and virtual worlds. ${ }^{18}$ Some authors have argued for propertisation claiming that emails or social network accounts and other assets are clearly users' property. ${ }^{19}$ However, this is not as simple as it sounds and legal and normative arguments go against this solution. ${ }^{20}$

First, it is important to note that user accounts are created through contracts between service providers and users, and the account itself and the underlying software is property/intellectual property of the service provider. ${ }^{21}$ However, the legal nature of the content itself is not as clear in law in most countries around the globe. If the content is an object of property, then the answer is simple for most European jurisdictions and the US: it transmits on death, through one's will or intestate succession. ${ }^{22}$ Conversely, if the content is not property stricto sensu, then it can be protected by copyright and, arguably transmits on death and last for as long as copyright lasts (70 years post-mortem mostly). ${ }^{23}$ This for most assets we have assessed is not easy to establish, as the law often requires tangibility, rivalrousness (the quality of an object that only one person can possess it without undermining its value) and other incidents or features that the law normally

${ }^{16}$ Edina Harbinja, "Legal Nature of Emails: A Comparative Perspective", 14 Duke Law and Technology Review 227, (2016), http://scholarship.law.duke.edu/dltr/vol14/iss1/10

${ }^{17}$ Edina Harbinja, "Social media and death".

${ }^{18}$ Edina Harbinja, "Virtual Worlds - a Legal Post-Mortem Account" SCRIPT-ed, 10(3), (2014): 273, https://script-ed.org/article/virtual-worlds-a-legal-post-mortem-account/

${ }^{19}$ Gregg Lastowka and Dan Hunter, "Virtual Worlds: A Primer" in The State of Play: Laws, Games, And Virtual Worlds, eds, J M Balkin and B Simone Noveck (NYU Press 2006): 13-28, 17-18; Wian Erlank Property in Virtual Worlds (PhD diss. Stellenbosch University, 2012): 22-23, http://ssrn.com/abstract=2216481; Jonathan Darrow and Gerald Ferrera, "Who Owns a Decedent's E-Mails: Inheritable Probate Assets or Property of the Network?" 10 N.Y.U. J. Legis. \& Pub. Pol'y, Vol. 281, (2006): 308; or Jason Atwater, "Who Owns Email? Do you have the right to decide the disposition of your private digital life?" Utah L.Rev, (2006): 397, 399; Jason Mazzone, “Facebook's Afterlife" 90 N.C. L. Rev., (2012): 1643; Natalie Banta, “Property Interests in Digital Assets: The Rise of Digital Feudalism" 38 Cardozo L. Rev., 1099 (2017) https://ssrn.com/abstract=3000026

${ }^{20}$ Harbinja, "Legal Aspects of Transmission of Digital Assets on Death"

21 Ibid 121, 220-225, $245-268$.

22 In the UK, for instance, 'a person's estate is the aggregate of all the property to which he is beneficially entitled' Inheritance Tax Act, s 5(1), applicable to England, Scotland, Wales and Northern Ireland; Wills Act 1837, s 3 (this Act does not extend its effect to Scotland); similarly, Succession (Scotland) Act 1964, s 32; Or, in the US, 'probate assets are those assets of the decedent, includible in the gross estate under IRC $\$ 2033$, that were held in his or her name at the time of death'; Darrow and Ferrera, "Who Owns a Decedent's E-Mails: Inheritable Probate Assets or Property of the Network?", 281; see also Laura McKinnon, "Planning for the Succession of Digital Assets" 27 CLSR, (2011): 362-67.

${ }^{23}$ Art 1 of Directive 2006/116/EC of the European Parliament and of the Council of 12 December 2006 on the term of protection of copyright and certain related rights (codified version) [2006] OJ L372/12 (Copyright Term Directive); Council Directive 93/98/EEC of 29 October 1993 harmonising the term of protection of copyright and certain related rights [1993] OJ L290/9; the 1976 Copyright Act, 17 USC §302; for a more in depth analysis of copyright see e.g. Harbinja, "Social media and death". 


$$
\begin{aligned}
& \text { This is a preprint of a chapter accepted for publication by Facet Publishing. } \\
& \text { This extract has been taken from the author's original manuscript and has not been edited. } \\
& \text { The definitive version of this piece may be found in 'Partners for Preservation: } \\
& \text { Advancing digital preservation through cross-community collaboration' Facet, London, } 9781783303472 \\
& \text { which can be purchased from http://www.facetpublishing.co.uk/title.php?id=303472\#about-tab }
\end{aligned}
$$

assigns to objects of property. Digital object do not fit squarely within these traditional legal concepts of property and ownership. ${ }^{24}$ Personal data, in particular, cannot be owned and many authors have argued against its propertisation, mainly European, ${ }^{25}$ whereas the US scholarship has been historically more inclined towards this concept. ${ }^{26}$

In terms of users' copyright, it is slightly more straight-forward, as a lot of assets would include copyrightable materials, especially when it comes to user-generated content. ${ }^{27}$ For instance, under section 1 of the UK Copyright, Designs and Patents Act 1988, copyright subsists in original literary, dramatic, musical or artistic works, sound recordings, films and the typographical arrangement of published editions. ${ }^{28}$ Thus, for instance, user posts, notes, poems, pictures and some videos would fall into these categories. In addition, they would to a great extent meet copyright requirements of fixation and originality in the US and UK law. ${ }^{29}$ As suggested above, this content would pass on after one death to their heirs for 70 years post-mortem in these jurisdictions and this is not debatable in terms of an entitlement. There is a problem in the UK copyright law regarding unpublished works, however. The Act requires that the unpublished work is embodied in a tangible medium. For instance, if posts on Facebook are considered unpublished (set to private or friends only), then heirs would not be entitled to copyright in this content since the tangibility is lacking. ${ }^{30}$

Generally, a problem that persists in all countries is the access to all this content by heirs and next of kin, and this will be discussed in the following section.

\section{Contracts and in-service solutions}

Every 'intermediary' (service provider, a platform that stores and/or enables digital assets) such as Facebook or Google, purports to regulate access to and ownership of user-created digital assets on its platforms according to its own terms of service/contract with their users. Thus, most issues of

\footnotetext{
${ }^{24}$ See Harbinja, "Legal Aspects of Transmission of Digital Assets on Death”, 121, 220-225, 245 - 268.

25 Jessica Litman, "Information privacy/information property" 52 Stanford Law Review, (2000): 1304; Julie Cohen, "Examined Lives: Informational Privacy and the Subject as Object" 52 Stanford Law Review, (2000): 1373-1426; Nadia Purtova, "Private Law Solutions in European Data Protection: Relationship to Privacy, and Waiver of Data Protection Rights" Netherlands Quarterly of Human Rights, 28 (2), (2010): 179-198, or conversely see Colette Cuijpers, "A private law approach to privacy; mandatory law obliged?", SCRIPT-ed, 24(4) (2007): 304-318; Harbinja, "Does the EU Data Protection Regime Protect Post-Mortem Privacy and What Could Be the Potential Alternatives?".

${ }^{26}$ Alan Westin, Privacy and freedom, (New York: Atheneum, 1967), 40; Kenneth Laudon, "Markets and privacy" Communications of the ACM, 39 (9), (1996): 96; Paul Schwartz, "Property, privacy, and personal data" Harvard Law Review 117, (2003): 2056-2128; Patricia Mell, "Seeking Shade in a Land of Perpetual Sunlight: Privacy as Property in the Electronic Wilderness" Berkeley Technology Law Journal 11, (1996): 1-79; Tal Zarsky, "Desperately seeking solutions: using implementation-based solutions for the troubles of information privacy in the age of data mining and the internet society", Maine Law Review 56, (2004): 13-59; Laurence Lessig, Code, version 2.0, (New York: Basic Books, 2006).

${ }^{27}$ Harbinja "Social media and death".

${ }^{28}$ UK Copyright, Design and Patents Act 1988 section 1.

${ }^{29}$ Harbinja "Social media and death". 188-192.

${ }^{30} \mathrm{lbid}$.
} 


$$
\begin{aligned}
& \text { This is a preprint of a chapter accepted for publication by Facet Publishing. } \\
& \text { This extract has been taken from the author's original manuscript and has not been edited. } \\
& \text { The definitive version of this piece may be found in 'Partners for Preservation: } \\
& \text { Advancing digital preservation through cross-community collaboration' Facet, London, } 9781783303472 \\
& \text { which can be purchased from http://www.facetpublishing.co.uk/title.php?id=303472\#about-tab }
\end{aligned}
$$

ownership and access to digital assets are determined at least at first by contract. This is not ideal perhaps, but it has an indisputable impact on transmission of digital assets on death. In particular, a phenomenon which has the potential to generate much uncertainty and litigation in the field of succession has just emerged which scholars have termed "in-service solutions" or sometimes "social media wills" ${ }^{31}$ Most platforms promise users 'ownership' of their content, ${ }^{32}$ however, the actual access and licence end on death and this undermine the initial promise, a user cannot pass this on to their heirs, for example.

Google, Facebook and others have introduced technical "legacy" tools, giving users choices to delete or transfer digital assets after death. These tools have the advantage of providing post-mortem control over personal data and digital assets to users who may never make a will,, ${ }^{33}$ as well as easy access to designated beneficiaries, but may also confound traditional estate administration process.

In 2013, Google introduced Inactive Account Manager (IAM), as the first in-service solution to address the issue of the transmission of digital assets on death. IAM enables users to share 'parts of their account data or to notify someone if they've been inactive for a certain period of time' ${ }^{34}$ According to the procedure, the user can nominate trusted contacts to receive data if the user has been inactive for a chosen time ( 3 to 18 months). The trusted contacts are, after their identity has been verified, entitled to download the data the user left to them. The user can also decide to only notify these contacts of the inactivity and to have all the data deleted. There is a link directly from the user's account settings (Personal Info and Privacy section) to the IAM. In addition, Google offers the following options if a user does not set up the Inactive Account Manager: closing the account of a deceased user, a request for funds from a deceased user's account, and obtaining data from a deceased user's account. The process is, however, discretionary and Google does not promise that any of the requests will be carried out. ${ }^{35}$

Similarly, Facebook's solution in its terms of use and privacy policy (known as the Statement of Rights and Responsibilities and the Data Use Policy) provides for three main options for dealing with assets on its site (accounts containing posts, pictures, videos etc): memorialization, deletion/deactivation, and Legacy Contact. ${ }^{36}$ The effects of memorialization are that it prevents anyone from logging into the account, even those with valid login information and password. Any user can send a private message to a memorialized account. Content that the decedent shared, while alive, remains visible to those it was shared with (privacy settings remain 'as is'). Depending on the privacy settings, confirmed Friends may still post to the decedent's timeline. Accounts which are memorialized no longer appear in the 'people you may know' suggestions or other suggestions and

${ }^{31}$ Edwards and Harbinja, "What Happens to My Facebook Profile When I Die? Legal Issues Around Transmission of Digital Assets on Death"; Harbinja, "Post-mortem Privacy 2.0: Theory, law and technology", 26-42; Naomi Cahn, Christina Kunz and Suzanne Brown Walsh, "Digital Assets and Fiduciaries", Research Handbook on Electronic Commerce Law, ed. John A. Rothchild, (Edward Elgar, 2016): 6-7, https://ssrn.com/abstract=2603398.

32 Harbinja, "Legal Aspects of Transmission of Digital Assets on Death".

33 Jane Denton, "More than $60 \%$ of the UK population has not made a will", This Money, September 26, 2016, http://www.thisismoney.co.uk/money/news/article-3807497/Nearly-60-Britons-not-written-will.html

34 "About Inactive Account Manager", Google Support, accessed June 1, 2018, https://support.google.com/accounts/answer/3036546?hl=en

${ }^{35}$ Harbinja, "Post-mortem Privacy 2.0: Theory, law and technology", 35-37.

${ }^{36}$ For a detailed analysis see Harbinja, “Post-mortem social media: law and Facebook after death", 180-188. 


$$
\begin{aligned}
& \text { This is a preprint of a chapter accepted for publication by Facet Publishing. } \\
& \text { This extract has been taken from the author's original manuscript and has not been edited. } \\
& \text { The definitive version of this piece may be found in 'Partners for Preservation: } \\
& \text { Advancing digital preservation through cross-community collaboration' Facet, London, } 9781783303472 \\
& \text { which can be purchased from http://www.facetpublishing.co.uk/title.php?id=303472\#about-tab }
\end{aligned}
$$

notifications. Memorialization prevents the tagging of the deceased in future Facebook posts, photographs or any other content. Unfriending a deceased person's memorialized account is permanent, and a friend cannot be added to a memorialized account or profile. Facebook provides the option of removal of a deceased's account, but with very general statements and vague criteria. The option is available only to 'verified immediate family members' or an executor and the relationship to the deceased needs to be verified. Facebook only promises that it will 'process' these requests, without giving a firm promise of fulfilling special requests. ${ }^{37}$

As of February 2015, Facebook allows its users to designate a friend or family member to be their Legacy Contact who is akin to a 'Facebook estate executor', who can manage their account after they have died. The Legacy Contact has a limited number of options: to write a post to display at the top of the memorialized Timeline; to respond to new friend requests and to update the profile picture and cover photo of a deceased user. In addition, a user 'may give their legacy contact permission to download an archive of the photos, posts and profile information they shared on Facebook. ${ }^{38}$ The Legacy Contact will not be able to log into the account or see the private messages of the deceased. All the other settings will remain the same as before memorialization of the account. Finally, an option is provided that permits a user to permanently delete his/her account after their death. ${ }^{39}$

These in-service solutions are partial but positive and a step in the right direction. They empower users and foster their autonomy and choice. ${ }^{40}$ They are a start towards what may become a much more comprehensive system of "social media wills" both in terms of the number of platforms offering such, and the number of options they present. Perhaps these in-service solutions may encourage young people to think about their future and make decisions about their digital assets. As digital assets created on platforms increase in number, value, and emotional and financial significance, this is socially useful. Platforms, however, need to do much more in order to raise awareness of these solutions and inform their users during registration, or later on, as a layered notice, a push notification, or a pop-up window, for instance.

The main problem with these tools is that their provisions might clash with a will (possibly made later in life), or the rules of intestate succession and heirs' interests. To illustrate this, a friend can be a beneficiary for Google or Facebook services, but they would not be heirs and next-of-kin, who would inherit copyright in one's asset for instance. I elsewhere suggest that the law should recognise these services as 'social media wills', and provide for legal solutions embraced by the US Uniform Law Commission in the Revised Uniform Fiduciary Access to Digital Assets Act (RUFADAA, see next section for more detail). ${ }^{41}$ The terms of service are also intrinsically unclear and contradictory and service providers need to make more effort to clarify them and make them more solid and coherent. Finally, there is no indication of how the UK and other consumers use these services, nor have service providers been cooperative with researchers and transparent to the public about this. Users

\footnotetext{
37 "Special request for a medically incapacitated or deceased person's account", Facebook, accessed June 1, 2018, https://en-gb.facebook.com/help/contact/228813257197480

38 "What data can a legacy contact download from Facebook?", Facebook, accessed June 1, 2018, https://www.facebook.com/help/408044339354739?helpref=faq content

${ }^{39}$ For a detailed analysis see Harbinja, "Post-mortem social media: law and Facebook after death", 180-188.

${ }^{40}$ Harbinja, "Post-mortem Privacy 2.0: Theory, law and technology".

${ }^{41}$ Ibid, 34-35.
} 
This is a preprint of a chapter accepted for publication by Facet Publishing. This extract has been taken from the author's original manuscript and has not been edited.

The definitive version of this piece may be found in 'Partners for Preservation:

Advancing digital preservation through cross-community collaboration' Facet, London, 9781783303472

which can be purchased from http://www.facetpublishing.co.uk/title.php?id=303472\#about-tab

should be made aware of these services and service providers need to make more effort in this regard.

\section{Post-mortem privacy}

A separate issue surrounding digital assets and death is post-mortem privacy, i.e. the protection of deceased's personal data. ${ }^{42}$ Many digital assets include a large amount of personal data (e.g. emails, social media content), and their legal treatment cannot be looked at holistically if one does not consider privacy laws and their lack of application post-mortem.

UK law, like many legal systems, does not protect post-mortem privacy. Protections for personality and privacy awarded by breach of confidence, data protection, and defamation all do not apply to the deceased in UK law. ${ }^{43}$ In English law, the principle has traditionally been actio personalis moritur cum persona, meaning personal causes of action die with the person, (see Baker v. Bolton). ${ }^{44}$ This principle has been revised by legislation in many contexts mainly for reasons of social policy, but it persists in relation to privacy and data protection. Similar applies to the US and many European countries. ${ }^{45}$

From the data protection perspective, the UK Data Protection Act 1998 in s. 1. defines personal data as 'data which relate to a living individual', denying any post-mortem rights. Same is envisaged in the Data Protection Bill 2017. The rationale behind not giving protection to the deceased's personal data in the UK is in the lack of the ability to consent to the processing of data. ${ }^{46} \mathrm{New}$ and infamous EU data protection, the General Data Protection Regulation, in Recital 27 permits member states to introduce some sort of protection for the deceased's data, and some states have already provided for this protection. ${ }^{47}$ The UK government's approach, therefore, is not an ideal situation and does not contribute to the legislative harmonisation within the EU, Brexit notwithstanding. I have argued on many occasions that post-mortem privacy deserves legal consideration in the UK, drawing an analogy with testamentary freedom, where individuals are permitted to control their wealth pre-mortem and their autonomy is extended on death. They, however, are not entitled to do the same for their online 'wealth', identities and personal data. ${ }^{48}$

\footnotetext{
${ }^{42}$ Ibid, or Lopez, "Posthumous Privacy, Decedent Intent, and Post-Mortem Access to Digital Assets".

${ }^{43}$ Edwards and Harbinja, "Protecting Post-Mortem Privacy: Reconsidering the Privacy Interests of the Deceased in a Digital World", 83-129.

${ }^{44}$ (1808) 170 Eng. Rep. 1033.

${ }^{45}$ Edwards and Harbinja, "Protecting Post-Mortem Privacy: Reconsidering the Privacy Interests of the Deceased in a Digital World", 83-129.

${ }^{46}$ UK House of Lords Select Committee on the European Communities, Report of the Protection of Personal Data, 1992.

${ }^{47}$ France and Hungary have already introduced some sort of protection of post-mortem privacy in their legislation, see Lucien Castex, Edina Harbinja and Julien Rossi, "Défendre les vivants ou les morts? Controverses sous-jacentes au droit des données post-mortem à travers une perspective comparée francoaméricaine" Réseaux, (2018) forthcoming.

${ }^{48}$ Harbinja, "Post-mortem Privacy 2.0: Theory, law and technology".
} 


$$
\begin{aligned}
& \text { This is a preprint of a chapter accepted for publication by Facet Publishing. } \\
& \text { This extract has been taken from the author's original manuscript and has not been edited. } \\
& \text { The definitive version of this piece may be found in 'Partners for Preservation: } \\
& \text { Advancing digital preservation through cross-community collaboration' Facet, London, } 9781783303472 \\
& \text { which can be purchased from http://www.facetpublishing.co.uk/title.php?id=303472\#about-tab }
\end{aligned}
$$

The problem of post-mortem privacy has already been observed in US ${ }^{49}$ and $\mathrm{German}^{50}$ jurisprudence and resolved in the US and French legislation. I will sketch the most significant features of these legislative efforts.

\subsection{US law - RUFADAA}

Similarly to the UK principles of non-survivorship of privacy and data protection, the US Restatement (Second) of Torts states that there can be no cause of action for invasion of privacy of a decedent, with the exception of 'appropriation of one's name or likeness. ${ }^{51}$ Some states do provide for the protection of so-called 'publicity rights' (rights that protect usually, celebrities, but sometimes all the individuals' right to name, image, likeness etc.) post-mortem, up to the limit of 100 years after death. ${ }^{52}$

On the other hand, interestingly, US states have been the most active jurisdictions in legislating the transmission of digital assets on death issues. The initial phase of the digital assets legislation started in 2005, with more than twenty US states having attempted to regulate the area of transmission of digital assets on death over the past ten years. These laws seem to have been inspired by the publicity around the Ellsworth case and similar controversies. In Ellsworth, Yahoo!, as an email provider, initially refused to give the family of a US marine, Justin Ellsworth, killed in Iraq access to his email account. They referred to their terms of service, which were designed to protect the privacy of the user by forbidding access to third parties on death. Yahoo! also argued that the US Electronic Communications Privacy Act of 1986 prohibits them from disclosing user's personal communications without a court order. The family argued that as his heirs, they should be able to access his emails and the entire account, his sent and received emails, as his last words. Yahoo!, on the other hand, had a non-survivorship policy and there was a danger that Ellsworth's account could have been deleted. The judge in this case, however, allowed Yahoo! to enforce their privacy policy and did not order transfer of the account log-in and password. Rather, he made an order requiring Yahoo! to enable access to the deceased's account by providing the family with a CD containing copies of the emails in the account. As reported by the media, Yahoo! originally provided only the emails received by Justin Ellsworth on a CD, and after the family had complained again, allegedly subsequently sent paper copies of the sent emails. ${ }^{53}$ This case clearly illustrates most of the issues in post-mortem transmission of emails and other digital assets (i.e. post-mortem privacy, access, and conflicts of interests of the deceased and family). Legislative responses that followed were partial and piecemeal, rather than comprehensive and evidence-based solutions. ${ }^{54}$

The answer to this scattered legislation and possible conflicts of law has been harmonisation within

\footnotetext{
49 In Re Ellsworth No. 2005-296, 651-DE (Mich. Prob. Ct. Mar. 4, 2005); Ajemian v. Yahoo!, Inc. SJC-12237

${ }^{50}$ Kammergericht, Urteil vom 31. Mai 2017, Aktenzeichen 21 U 9/16

https://www.berlin.de/gerichte/presse/pressemitteilungen-der-ordentlichengerichtsbarkeit/2017/pressemitteilung.596076.php

${ }^{51}$ Restatement (Second) of Torts § 652। (1977)

52 "Protecting Post-Mortem Privacy: Reconsidering the Privacy Interests of the Deceased in a Digital World", 124.

${ }^{53}$ See Ada Kulesza, "What Happens to Your Facebook Account When You Die?", Blog, February 3, 2012 http://blogs.lawyers.com/2012/02/what-happens-to-facebook-account-when-you-die/; Associated Press release (justinelsworth.net, April 21 2005) at http://www.justinellsworth.net/email/ap-apr05.htm.

54 See Lopez, "Posthumous Privacy, Decedent Intent, and Post-Mortem Access to Digital Assets".
} 


$$
\begin{aligned}
& \text { This is a preprint of a chapter accepted for publication by Facet Publishing. } \\
& \text { This extract has been taken from the author's original manuscript and has not been edited. } \\
& \text { The definitive version of this piece may be found in 'Partners for Preservation: } \\
& \text { Advancing digital preservation through cross-community collaboration' Facet, London, } 9781783303472 \\
& \text { which can be purchased from http://www.facetpublishing.co.uk/title.php?id=303472\#about-tab }
\end{aligned}
$$

the US. In July 2012 the US Uniform Law Commission formed the Committee on Fiduciary Access to Digital Assets. The goal of the Committee was to draft act and/or amendments to Uniform Law Commission acts (the Uniform Probate Code, the Uniform Trust Code, the Uniform Guardianship and Protective Proceedings Act, and the Uniform Power of Attorney Act) that would authorise fiduciaries to manage and distribute, copy or delete, and access digital assets. Starting from 2012, for the purposes of Committee meetings, The Uniform Fiduciary Access to Digital Assets Act (UFADAA) had been drafted and published online on multiple occasions. ${ }^{55}$ The process included fierce lobbying efforts by the big tech companies (e.g. Google and Facebook), connected through a think tank called NetChoices. The companies even moved on to lobby for a completely different act, which would replace the UFADAA, resulting in The Privacy Expectation Afterlife and Choices Act 2015 (PEAC). The Uniform Law Commission then decided to revise the UFDAA, and incorporate some of the industry concerns and pro-privacy stances, adopting the Revised UFADAA (RUFADAA) in 2015..$^{56}$

Although this initiative was an attempt to improve and develop the existing statutes aiming to consider the full range of digital assets, there were many open issues that the Committee needed to address when drafting the RUFADAA. For instance, in the Prefatory Note for the Drafting Committee in the February 2013 Draft, the drafters identify the most critical issues to be clarified, including the definition of digital property (section 2) and the type and nature of control that can be exercised by a fiduciary (section 4). It seems that some of the most controversial issues were being disputed within the Committee, such as clarifying possible conflicts between contract and executry law, and between heirs, family, and friends. ${ }^{57}$

The RUFADAA includes important powers for fiduciaries regarding digital assets and estate administration. These powers are limited by a user's will and intent expressed in his choice to use online tools to dispose of his digital assets (e.g. Google Inactive Account Manager). User's choice overrides any provisions of his will. If the user does not give direction using an in-service solution, but makes provisions for the disposition of digital assets, the RUFADAA gives legal effect to the user's directions. If the user fails to give any direction, then the provider's terms of service (ToS) will apply. The Act also gives the service provider a choice of methods for disclosing digital assets to an authorised fiduciary, in accordance with their ToS (i.e. full access, partial access, or a copy in a record). Finally, the Act gives personal representatives default access to the "catalogue" of electronic communications and other digital assets not protected by federal privacy law (i.e. the content of communication which is protected and can only be disclosed if the user consented to disclosure or if a court orders disclosure). Additionally, section 9. of RUFADA aims to resolve the issues of the potential violations of criminal and privacy legislation. It also tackles jurisdiction, mandating that the choice of law provisions in ToS do not apply to fiduciaries. Apart from that, the new draft abandoned the digital property notion altogether and left only the digital assets, comprising both the content and the log information (information about an electronic communication, the date and time a message has been sent, recipient email address etc.).

\footnotetext{
55 Ibid.

56 Ibid.

${ }^{57}$ Harbinja, "Legal Aspects of Transmission of Digital Assets on Death".
} 


$$
\begin{aligned}
& \text { This is a preprint of a chapter accepted for publication by Facet Publishing. } \\
& \text { This extract has been taken from the author's original manuscript and has not been edited. } \\
& \text { The definitive version of this piece may be found in 'Partners for Preservation: } \\
& \text { Advancing digital preservation through cross-community collaboration' Facet, London, } 9781783303472 \\
& \text { which can be purchased from http://www.facetpublishing.co.uk/title.php?id=303472\#about-tab }
\end{aligned}
$$

So far, a vast majority of states have introduced and enacted the RUFADA. ${ }^{58}$ Most of these states have already had their own digital assets statutes. However, this legislation had not been harmonised before RUFADAA, so the Act contributed to the harmonisation of divergent laws -- at least in the states that enacted the RUFADA. Notably, California, where the biggest service providers are based and whose laws are applicable to the ToS, has not introduced the legislation. Hopefully, the Act will achieve a wider adoption and application in the individual states, or even initiate similar efforts in other countries. An acceptable legal solution for the transmission of emails will ideally follow the rationale behind the RUFADAA. It should aim to recognise technology as a way of disposing of digital assets (including emails), as a more efficient and immediate solution online. The solution would also consider technological limitations, users' autonomy, and the changing landscape of relationships online..$^{59}$

The Uniform Law Conference of Canada followed this approach and enacted a similar act: the Canadian Uniform Access to Digital Assets by Fiduciaries Act 2016 (UADAFA)..$^{60}$ This Act provides a stronger right of access for fiduciaries than the RUFADA. There is a default access to the digital assets of the account holder. In UAFADA, the instrument appointing the fiduciary determines a fiduciary's right of access, rather than the service provider. The Canadian Act has a "last-in-time" priority system, whereby the most recent instruction takes priority over an earlier instrument. Interestingly, however, a user who already has a will, but nominates a family member or a friend to access their social media account after their death, restricts their executor's rights under the will. This is similar to the US RUFADA in that the deceased's will takes priority in any case, the difference is in the mechanism. The RUFADA is more restrictive in honouring ToS in the absence of a user's instruction. Service providers are obliged only to disclose the catalogue of digital assets, and not the content. I believe that this solution is more suitable for the online environment, in particular where assets are intrinsically tied to one's identity (communications, social networks, multiple account with one providers such as Google, where these create a unique profile and identity of a user etc.).

In the Digital Republics Act 2016, France has adopted a solution quite similar to the RUFADAA. ${ }^{61}$ Article 63(2) of the Act states that anyone can set general or specific directives for preservation, deletion, and disclosure of his personal data after death. ${ }^{62}$ These directives would be registered with a certified third party (for general ones) or with the service provider who holds the data (e.g. Facebook and their policy described above). This is quite a surprising development that brings the US and French approaches to post-mortem privacy closer. This is even odder if we consider conventional

\footnotetext{
58 US Uniform Law Commission, "Fiduciary Access to Digital Assets Act, Revised (2015): 2018 Introductions \& Enactments",

http://www.uniformlaws.org/Act.aspx?title=Fiduciary\%20Access\%20to\%20Digital\%20Assets\%20Act,\%20Revis ed\%20(2015).

${ }^{59}$ Elaine Kasket, "Access to the Digital Self in Life and Death: Privacy in the Context of Posthumously Persistent Facebook Profiles" SCRIPTed 7, 10, (2013); Natalie Pennington, "You Don't De-Friend the Dead: An Analysis of Grief Communication by College Students Through Facebook Profiles" Death Studies 37, (2013): 617.

60 Uniform Law Conference of Canada, Uniform Access to Digital Assets by Fiduciaries Act (2016) https://www.ulcc.ca/images/stories/2016 pdf en/2016ulcc0006.pdf

${ }^{61}$ LOI n 2016-1321 du 7 octobre 2016 pour une République numérique

${ }^{62}$ For more see Lucien Castex, Edina Harbinja and Julien Rossi, "Défendre les vivants ou les morts? Controverses sous-jacentes au droit des données post-mortem à travers une perspective comparée francoaméricaine".
} 


$$
\begin{aligned}
& \text { This is a preprint of a chapter accepted for publication by Facet Publishing. } \\
& \text { This extract has been taken from the author's original manuscript and has not been edited. } \\
& \text { The definitive version of this piece may be found in 'Partners for Preservation: } \\
& \text { Advancing digital preservation through cross-community collaboration' Facet, London, } 9781783303472 \\
& \text { which can be purchased from http://www.facetpublishing.co.uk/title.php?id=303472\#about-tab }
\end{aligned}
$$

and extremely divergent approaches of these jurisdictions to protecting personal data of the living individuals. ${ }^{63}$

We will not be seeing similar developments in the UK unfortunately. Relevantly, the Law Commission has recently initiated the reform of the law of wills in England and Wales. In their consultation brief, they assert that digital assets '...fall outside the sort of property that is normally dealt with by a will' ${ }^{64}$ and that digital assets are primarily a matter of contract law and could be addressed in a separate law reform. This suggestion fails to future proof the law of wills as these kinds of assets become more common and more valuable. In the future, we will see conflicts between wills and the disposition of digital assets online, and this reform is a chance for UK law to show foresight in anticipating these issues, and to follow good examples in other countries, as explained above. With Lilian Edwards, I have, therefore, argued that the Commission should consider digital assets in the ongoing reform, in order to forestall rather than create unclarity and confusion. We will see quite soon whether the Commission will take our suggestion on board and take this opportunity to bring about some clarity in the law.

\section{Digital estate planning and potential solutions}

Digital estate planning is a developing area, with many tech solutions being developed over the years. Given the lack of regulation and law, this was perceived as a quick solution to deal with digital assets on death. ${ }^{65}$

They aim to shift the control of digital assets to users by enabling designation of beneficiaries who will receive passwords/content of digital asset accounts. Lamm et al. categorise these solutions somewhat differently, focusing on the character of actions they promise to undertake on death. They find four categories: services offering to store passwords; services facilitating administration of digital assets; services performing specific actions (e.g. removing all the data on behalf of a deceased person), and services that currently do not exist, but hypothetically provide their services through partnerships with service providers of the deceased's accounts ${ }^{66}$ This categorisation is very similar to the one I used earlier, with the slight difference that it focuses on actions rather than on business models. ${ }^{67}$

In their earlier work, Edwards and Harbinja evaluated some of the 'code' solutions and concluded that 'these are not themselves a foolproof solution' ${ }^{68}$ for five main reasons: 1 . they could cause a

\footnotetext{
63 Ibid

${ }^{64}$ The Law Commission, “Making a will”, Consultation paper 231, 2017, https://s3-eu-west2.amazonaws.com/lawcom-prod-storage-11jsxou24uy7q/uploads/2017/07/Making-a-will-consultation.pdf

65 Jamie Hopkins, "Afterlife in the Cloud: Managing a Digital Estate", Hastings and Science Technology Law
}

Journal, 5, (2013): 229; Gerry W. Beyer \& Naomi Cahn, “When You Pass On, Don't Leave the Passwords

Behind: Planning for Digital Assets" Probate \& Property 26, (2012): 40.

$66 \mathrm{Jim}$ Lamm et al., "The Digital Death Conundrum: How Federal and State Laws Prevent Fiduciaries from Managing Digital Property" U. MIAMI L. REV. 68, (2014), 408.

${ }^{67}$ Harbinja, "Legal Aspects of Transmission of Digital Assets on Death".

${ }^{68}$ Edwards and Harbinja, "What Happens to My Facebook Profile When I Die?': Legal Issues Around Transmission of Digital Assets on Death", 144. 


$$
\begin{aligned}
& \text { This is a preprint of a chapter accepted for publication by Facet Publishing. } \\
& \text { This extract has been taken from the author's original manuscript and has not been edited. } \\
& \text { The definitive version of this piece may be found in 'Partners for Preservation: } \\
& \text { Advancing digital preservation through cross-community collaboration' Facet, London, } 9781783303472 \\
& \text { which can be purchased from http://www.facetpublishing.co.uk/title.php?id=303472\#about-tab }
\end{aligned}
$$

breach of terms of service (due to the non-transferable nature of most assets, as suggested above); 2. There is a danger of committing a criminal offence (according to the provisions of the antiinterception and privacy laws); 3 . The services are inconsistent with the law of succession/executry (they do not fulfil requirements of will formalities; conflicts with the interests of heirs under wills or laws of intestacy may arise; jurisdiction issues etc.); 4 . There are concerns over the business viability and longevity of the market and services; 5 . the issues of security and identity theft (the services store passwords and keys to valuable assets and personal data). ${ }^{69}$ Beyer and Cahn, and Lamm et al. identify most of these problems as well. ${ }^{70}$ Öhman and Floridi criticise these from a philosophical perspective as well, submitting that these services commercialise death and dying and violate dignity of the deceased. ${ }^{71}$

It is thus not recommended that the services are used in their current form and with the law as it stands now. However, with improvements in the services and their recognition by the law, they do have a potential to be used more widely in the future. In principle, the services are more suitable for the digital environment, as they recognise the technological features of digital assets and enable an automatic transmission on death. However, due to the issues surrounding them as suggested above, the author does not envisage their legitimate reception in the near future, at least not outside the US.

In the UK, at the moment, a widespread practice is that the testators are advised by solicitors to list their accounts and passwords for their heirs to use after his death. ${ }^{72}$ This solution is in breach of most user agreements which could conceivably lead to premature termination of the account. Passwords should change over time and testators may not remember to update the list that they prepared at the time they made their will. Leaving a list like this is also very insecure and leaves users vulnerable to security breaches and hacking. Therefore, although this advice may be practical, they do not overcome the issues discussed above.

\section{Conclusions}

This chapter examined key issues related to digital assets and inheritance. The area is very complex and digital assets need to be examined individually in order to be able to determine what regulatory and legal regime is best suited to deal with their post-mortem transmission. However, what is common for most assets is that they include a myriad of legal relationships and that these surface differently for different types of these assets. For instance, copyright might be more important in an asset that includes a number of photographs, poems or stories, property might be in question for music libraries, and post-mortem privacy is a more obvious concern for assets that are more intrinsically related to an individual. Notwithstanding this distinction, all of them have in common that there are governed primarily by intermediary contracts and that the lack of laws and regulation gives prevalence to these in many jurisdictions. There have been some innovative solutions in countries such as America or France, but there is still work to do to implement these in practice and

69 Ibid.

${ }^{70}$ Cahn, "Probate Law Meets the Digital Age", 1706; Lamm et.al. "The Digital Death Conundrum: How Federal and State Laws Prevent Fiduciaries from Managing Digital Property" (400-401).

${ }^{71}$ Carl Öhman, C. \& Luciano Floridi, "The Political Economy of Death in the Age of Information: A Critical Approach to the Digital Afterlife Industry", Minds \& Machines 27, (2017): 639.

https://doi.org/10.1007/s11023-017-9445-2

72 The Law Commission, "Making a will". 
This is a preprint of a chapter accepted for publication by Facet Publishing. This extract has been taken from the author's original manuscript and has not been edited. The definitive version of this piece may be found in 'Partners for Preservation:

Advancing digital preservation through cross-community collaboration' Facet, London, 9781783303472 which can be purchased from http://www.facetpublishing.co.uk/title.php?id=303472\#about-tab

test them as technology develops. Other countries, such as the UK, still have a long way to go and this author has been involved in the ongoing reforms in the area. It is important that legislators and regulators in this country follow good examples and clarify this muddled and complex area. Technology is one way to go, but again, innovative service provider solutions may not be followed by legislative reforms and often conflict with some longstanding legal principles in succession, intellectual property, privacy, or property law.

It is, therefore, necessary to introduce some digital assets specific laws in countries where this is not the case, such as the UK. These would ideally recognise user autonomy and post-mortem privacy that can be expressed in one's will as well as in-service solutions. In the UK, this could be done as part of the ongoing reforms of the law of will, as well as amendments to the data protection laws. Generally, all countries who aim to legislate in the area need to make sure that their property, contract, IP, data protection, and succession laws are consistent, otherwise, efforts in one area may be undermined by its conflicting provisions in other areas of law. In addition, there should be exceptions to these genera; provisions in order enable access by researchers and archivists, in particular, so to balance the right to privacy, autonomy with the freedom of expression and the interests of the public. This is particularly important for the cases where users may choose to be forgotten post-mortem, i.e. to have most of their accounts and data deleted. Here, as generally required by the data protection and many other laws, privacy and individual rights need to be balanced against the rights of the public, such as the freedom of expression, research, and archival interests. This, however, does not prevent legislators and user from regulating and promoting user autonomy when it comes to digital assets and online data and death. 